\title{
Bioinoculation of Mustard (Brassica juncea L.) with Beneficial Rhizobacteria: A Sustainable Alternative to Improve Crop Growth
}

\author{
Ruchi Sharma, Swati Sindhu and Satyavir Singh Sindhu*
}

Department of Microbiology, CCS Haryana Agricultural University, Hisar - 125004, India

*Corresponding author

\begin{tabular}{l} 
Ke y w or d s \\
$\begin{array}{l}\text { Rhizobacteria, Mustard, } \\
\text { Indole acetic acid, } \\
\text { Potassium solubilization, } \\
\text { Plant growth }\end{array}$ \\
\hline Article Info \\
$\begin{array}{l}\text { Accepted: } \\
12 \text { April } 2018 \\
\text { Available Online: } \\
10 \text { May } 2018\end{array}$ \\
\hline
\end{tabular}

A B S T R A C T

\begin{abstract}
Indian mustard (Brassica juncea L.) occupies third place among the various oilseed crops due to its considerable economic and nutritional value. Many naturally-occurring rhizosphere bacteria colonize its roots and benefit plants by enhancing the availability of nutrients. In this study, seventy eight bacterial isolates were obtained from the rhizosphere of mustard and screened for beneficial characteristics. Thirty two rhizobacterial isolates produced indole acetic acid ranging from 1.08 to $19.95 \mu \mathrm{g} / \mathrm{ml}$. Thirty-five rhizobacterial isolates showed $\delta$-aminolevulinic acid production varying from 1.02 to $15.62 \mu \mathrm{g} / \mathrm{ml}$. Thirteen isolates solubilized bound potassium on mica containing Aleksandrov medium plates and only five rhizobacterial isolates showed phosphorus solubilizing activity on Pikovskaya's medium plates. Seed bacterization of mustard with rhizobacterial isolates HMR29 and HMR56 showed 77.5 and $47.5 \%$ increase in shoot dry weight, respectively as compared to uninoculated plants at 25 days of growth. At 50 days of plant growth, single inoculation of rhizobacterial isolates, HMR29 and HMR56 showed 108.8 and $150.63 \%$ increase in shoot dry weight in comparison to uninoculated control. Inoculation with isolates HMR29 and HMR73 caused 110.0 and $48.64 \%$ increase in shoot dry weight as well as 40.0 and $6.0 \%$ increase in root dry weight, respectively at 75 days of growth as compared to uninoculated control.
\end{abstract}

\section{Introduction}

Some of the free-living bacteria in the plant rhizosphere have the potential to increase plant growth and are termed as plant growth promoting rhizobacteria (PGPR) (Bashan and Holgium, 1998). These PGPR synthesize vitamins, amino acids, auxins and gibberellins (Dubeikovsky et al., 1993; Malik and Sindhu, 2011) and regulate ethylene production in roots, cause solubilization and uptake of mineral nutrients (Pii et al., 2015), and may inhibit the growth of potential plant pathogens
(Sindhu et al., 2009; Sahu and Sindhu, 2011). Soil microorganisms possessing these beneficial characteristics are used as bioinoculants to improve the productivity of various crops in sustainable agriculture (Welbaum et al., 2004; Compant et al., 2010; Sindhu et al., 2016).

Thus, inoculation of crop plants with PGPR strains offers an ecofriendly alternative to minimize the use of chemical fertilizers for improving crop production (Franche et al., 2009; Sindhu et al., 2010). 
Different plant growth-promoting rhizobacteria including Azotobacter, Bacillus, Burkholderia and Pseudomonas have been reported to affect plant growth directly or indirectly (Sindhu et al., 1997; Taghavi et al., 2009). Inoculation with bacteria having the ability to produce $\delta$-aminolevulinic acid (ALA) and potassium solubilization has been reported to improve growth of different plants (Hotta et al., 1997; Basak and Biswas, 2010; Liu et al., 2014). Prajapati and Modi (2016) reported that inoculation with potassium solubilizing bacteria Enterobacter hormaechei KSB-8 caused a remarkable increase in root length, flowering, fruit setting, fruit maturing, $\mathrm{K}$ content and chlorophyll content in cucumber (Cucumis sativus). Similarly, Bacillus cytaseus $21 \mathrm{~N}$ inoculation improved seed germination and caused stimulation of melilot's growth (Smirnova et al., 2016). Presowing seed inoculation with B. cytaseus $21 \mathrm{~N}$ increased the germination of the melilot seeds up to $70-75 \%$ and green mass yield by $8-10$ t/ha. Six native peanut bacteria possessing the ability to solubilize tricalcium phosphate under abiotic stress, increased seed germination, plants' growth and $\mathrm{P}$ content in peanut and maize (Anzuay et al., 2017).

Indian mustard (Brassica juncea L.) is an important oilseed crop grown across the Northern Indian plains. It is often grown for edible leaves and as an oilseed crop. Mustard straw is also being widely used in the brick kiln as a source of fuel, which gives additional return for the crop produce. Limited efforts have been made to characterize the PGPR for growth improvement of this commercial crop. In this study, different rhizobacteria were evaluated for beneficial characteristics and four rhizobacterial isolates were finally used for inoculation studies of mustard under pot house conditions. Inoculation with rhizobacterial isolates HMR29 and HMR73 caused significant gain in root and shoot dry weight of mustard plants.

\section{Materials and Methods}

\section{Isolation of bacteria from rhizosphere soil}

Soil samples from mustard rhizosphere were collected from six different field locations of CCS Haryana Agricultural University, Hisar farm at 60 and 90 days of plant growth. From each location, samples were pooled to make composite sample of representative location. The serial dilutions of the composite soil samples (up to $10^{-5}$ ) were plated on Luria Bertani (LB) agar medium (Sambrook et al., 1989) plates. Colonies were selected based on morphological and pigment production characteristics after 3 days of incubation at $28 \pm 2{ }^{\circ} \mathrm{C}$. Seventy eight bacterial colonies were purified by streaking on LB medium plates and isolated single colonies were transferred on LB medium slopes. Liquid cultures of all the selected rhizobacterial isolates were preserved in $50 \%$ glycerol at $-20^{\circ} \mathrm{C}$.

\section{Screening of rhizobacterial isolates for indole acetic acid (IAA) production}

Rhizobacterial isolates were tested for their ability to produce indole acetic acid using Salkwoski's Reagent (Gordon and Weber, 1951). Bacterial cultures from LB slopes were transferred into LB broth $(5 \mathrm{ml})$ supplemented with L- tryptophan $(100 \mu \mathrm{g} / \mathrm{ml})$ and were incubated at $28 \pm 2^{\circ} \mathrm{C}$ for 4 days. Growth suspension was centrifuged for $5 \mathrm{~min}$ at $10,000 \mathrm{rpm}$. Two $\mathrm{ml}$ of Salkowski's reagent was added to two ml of culture supernatant, mixed and allowed to stand for $30 \mathrm{~min}$ for the development of pink colour. Absorbance was determined at $500 \mathrm{~nm}$ wavelength using spectrophotometer

spectrophotometer 117, Systronics, Ahemadabad, India) against a reagent blank. Indole acetic acid $(100 \mu \mathrm{g} / \mathrm{ml})$ was used as standard and results were expressed as $\mu \mathrm{g}$ IAA produced per $\mathrm{ml}$ of culture supernatant. Uninoculated LB broth served as control. 


\section{Production of $\boldsymbol{\delta}$-aminolevulinic acid (ALA)}

Rhizobacterial isolates were tested for their ability to produce $\delta$-aminolevulinic acid using the method as described by Mauzerall and Granick (1955). Cultures were inoculated in duplicate in $10 \mathrm{ml} \mathrm{LB}$ broth supplemented with $15 \mathrm{mM}$ glycine and succinate, and were incubated at $28 \pm 2^{\circ} \mathrm{C}$ for $48 \mathrm{hrs}$ under stationary conditions. Culture samples (1.5 $\mathrm{ml}$ ) were withdrawn and centrifuged at 10,000 rpm for 15 min (Remi Instruments, Mumbai, India). To $0.5 \mathrm{ml}$ of culture supernatant, $50 \mu 1$ of acetylacetone and $0.5 \mathrm{ml}$ of $1 \mathrm{M}$ sodium acetate buffer were added. Tubes were boiled in a water bath for $15 \mathrm{~min}$. After cooling, 3.5 $\mathrm{ml}$ of modified Ehrlich's reagent was added and the absorbance of the mixture was measured at $556 \mathrm{~nm}$ wavelength after $20 \mathrm{~min}$ at room temperature. The concentration of ALA in the culture supernatant of different rhizobacterial isolates was determined by using standard curve.

Screening of rhizobacterial isolates for potassium solubilisation

Potassium solubilization by rhizobacterial isolates was studied on modified Aleksandrov medium plates containing insoluble mica powder as potassium source by the spot test method (Parmar and Sindhu, 2013). A loopful of 48-hours old growth of rhizobacterial isolate was spotted on modified Aleksandrov's medium plates. Ten bacterial cultures were spotted on each plate and plates were incubated at $28 \pm 2^{\circ} \mathrm{C}$ for 3 days. Potassium solubilizing activity was determined by formation of solubilization zone and solubilization index (K-SI) was calculated for each rhizobacterial isolate by the following formula:

Potassium solubilizing index $(\mathrm{K}-\mathrm{SI})=($ Colony diameter + Clear zone diameter $) /($ Colony diameter)

\section{Phosphorus solubilization by rhizobacterial isolates}

Phosphorus solubilization by rhizobacterial isolates was studied on Pikovskaya's medium plates by the spot test method (Sharma et al., 2011). A loopful of 48-hour old growth of rhizobacterial isolate was spotted on above prepared medium plates. Ten bacterial cultures were spotted on each plate and plates were incubated at $28 \pm 2^{\circ} \mathrm{C}$ for 7 days. Phosphorus solubilization by different rhizobacterial isolates was scored, based upon their ability of solubilization zone formation.

\section{Inoculation effect of selected rhizobacterial isolates on mustard crop}

Four rhizobacterial isolates i.e., HMR29, HMR56, HMR70 and HMR73 were selected for seed inoculation of mustard. The earthen pots of $10 \mathrm{~kg}$ capacity were filled with sandy loam soil and river sand mixed in 70:30 ratio. Recommended doses of fertilizers (RDF) for mustard were applied at sowing stage. Rhizobacterial isolates were grown on LB medium broth $(20 \mathrm{ml})$ for 3 days. Seeds of mustard variety RH749 (10 g) were inoculated with $10 \mathrm{ml}$ of bacterial growth suspension. The viable count in the broth was kept at a population of $10^{8}-10^{9}$ cells $/ \mathrm{ml}$. Uninoculated seeds were sown as control. The inoculated seeds were grown in the pot house under day light conditions. Plants were watered as and when required. Plants were uprooted at 25, 50 and 75 days of plant growth. After washing with tap water, plant biomass was dried in the folds of filter paper. Shoot and root portions of the plants were dried in oven at $90^{\circ} \mathrm{C}$ for $24 \mathrm{~h}$ and weighed.

\section{Statistical analysis}

Completely randomized design (CRD) was used for experimental data analysis. All determinations were carried out in triplicate 
and data represented are average values of three replications. C.D. values represent coefficient of deviation.

\section{Results and Discussion}

The present study was planned to characterize rhizobacterial strains that possessed the beneficial attributes and could be used as bioinoculant for mustard crop. Seventy eight rhizobacterial isolates were selected from rhizosphere soil of mustard and screened for production of IAA, ALA and solubilization of phosphorus as well as potassium. Selected rhizobacterial isolates were tested for plant growth promotion of mustard under pot house conditions.

Production of IAA and ALA by different rhizobacterial isolates

Production of phytohormones has been a dominant mechanism of plant growth promotion by rhizobacteria. Rhizobacterial isolates were tested for production of IAA at 4 days of growth. Thirty two rhizobacterial isolates produced IAA ranging from 1.08 to $19.95 \mu \mathrm{g} / \mathrm{ml}$ (Table 1). Four rhizobacterial isolates HMR2, HMR32, HMR39 and HMR57 produced > $15 \mu \mathrm{g} / \mathrm{ml}$ IAA. Ten rhizobacterial isolates produced $>10 \mu \mathrm{g} / \mathrm{ml}$ IAA, whereas two isolates HMR3 and HMR65 produced 9.66 and $8.58 \mu \mathrm{g} / \mathrm{ml}$ IAA, respectively. Quantitative estimation for ALA production showed that nineteen isolates produced $>10 \mu \mathrm{g} / \mathrm{ml}$ ALA and nine isolates produced between 6.45 and $9.66 \mu \mathrm{g} / \mathrm{ml}$ ALA (Table 1).

\section{Potassium and phosphorus solubilization by different rhizobacterial isolates}

Potassium solubilisation ability of different rhizobacterial isolates was scored depending on the ability of bacteria to form zone of solubilization. Only 13 isolates formed significant zone of $\mathrm{K}$ solubilization on mica containing medium (Table 2; Fig. 1). Six rhizobacterial isolates i.e. HMR56, HMR73, HMR29, HMR52, HMR55 and WHA64 showed potassium-solubilising index (K-SI) more than 3.0. Five rhizobacterial isolates showed K-SI more than 2.0, whereas no potassium-solubilizing activity was observed in 33 rhizobacterial isolates. In the present study, only five rhizobacterial isolates showed P solubilization i.e., HMR3, HMR52, HMR59, HMR48, HMR25 (Table 2).

Inoculation effect of selected rhizobacterial isolates on root and shoot growth of mustard

Four rhizobacterial isolates i.e., HMR29, HMR56, HMR70 and HMR73 were used for inoculation of mustard seeds (variety RH749). Inoculation of rhizobacterial isolates HMR29 and HMR56 showed 77.5 and 47.2\%, increase in shoot dry weight, respectively as compared to uninoculated plants at 25 days of growth (Table 3). Inoculation with rhizobacterial isolate HMR70 caused $45.4 \%$ increase in root dry weight. At 50 days of growth, inoculation of rhizobacterial isolates HMR29 and HMR56 showed 150.63 and $108.80 \%$ increase in shoot dry weight, respectively in comparison to uninoculated control. Inoculation with rhizobacterial isolate HMR73 caused $64.5 \%$ increase in root dry weight as compared to uninoculated control.

At 75 days of growth, inoculation with isolates HMR29 and HMR73 showed 110.0 and $48.6 \%$ gain in shoot dry weight and caused 40.0 and $6 \%$ increase in root dry weight, respectively as compared to uninoculated control. Rhizobacterial isolate HMR29 showed significant increase in shoot dry weight at all the three stages of plant growth (Fig. 2), whereas significant gain in shoot dry weight was also observed by inoculation of HMR70 and HMR73. 
Fig.1 [A] Solubilization of potassium by selected rhizobacterial isolates; [B] Solubilization of phosphorus by selected rhizobacterial isolates
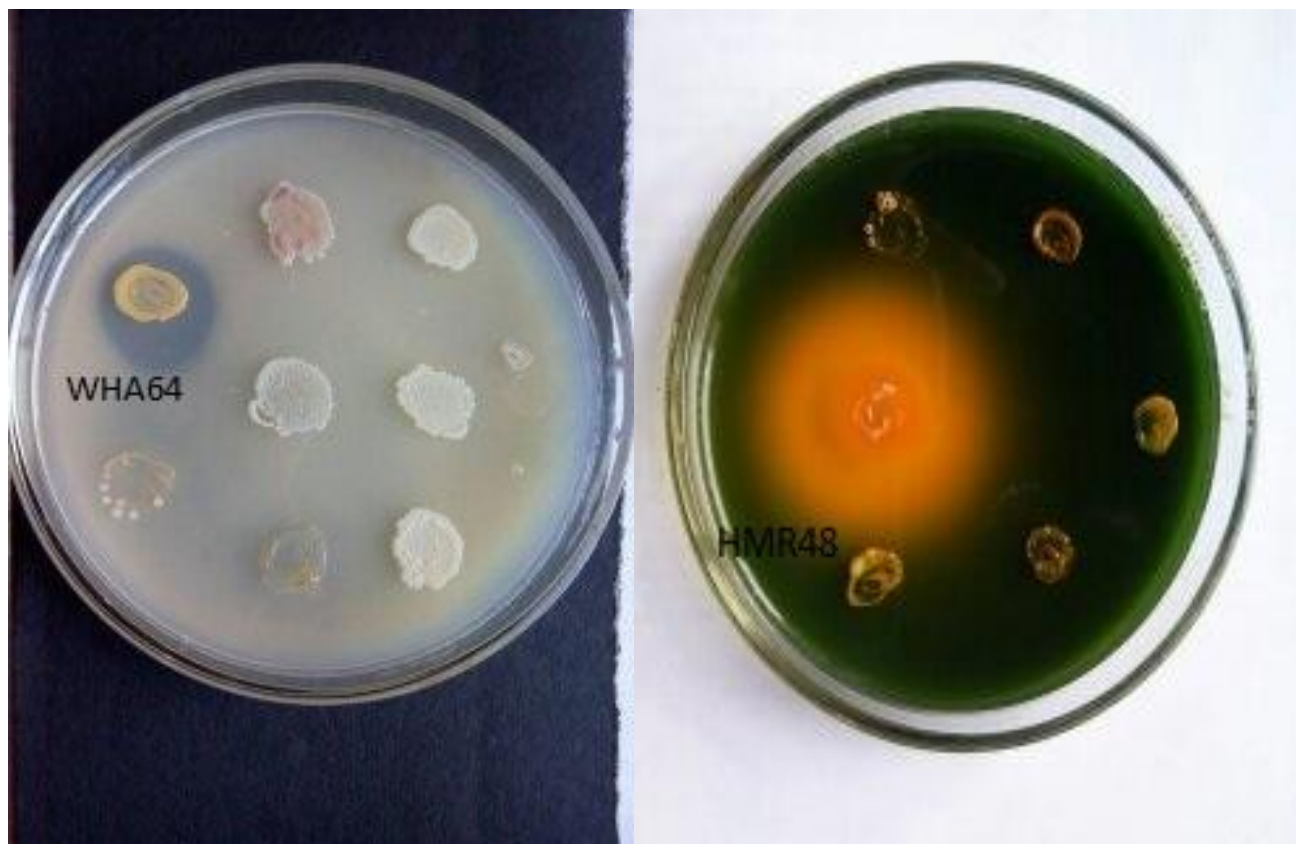

Fig.2 Growth promoting effects of rhizobacterial isolates on shoot dry weight of mustard at 25, 50 and 75 days after sowing

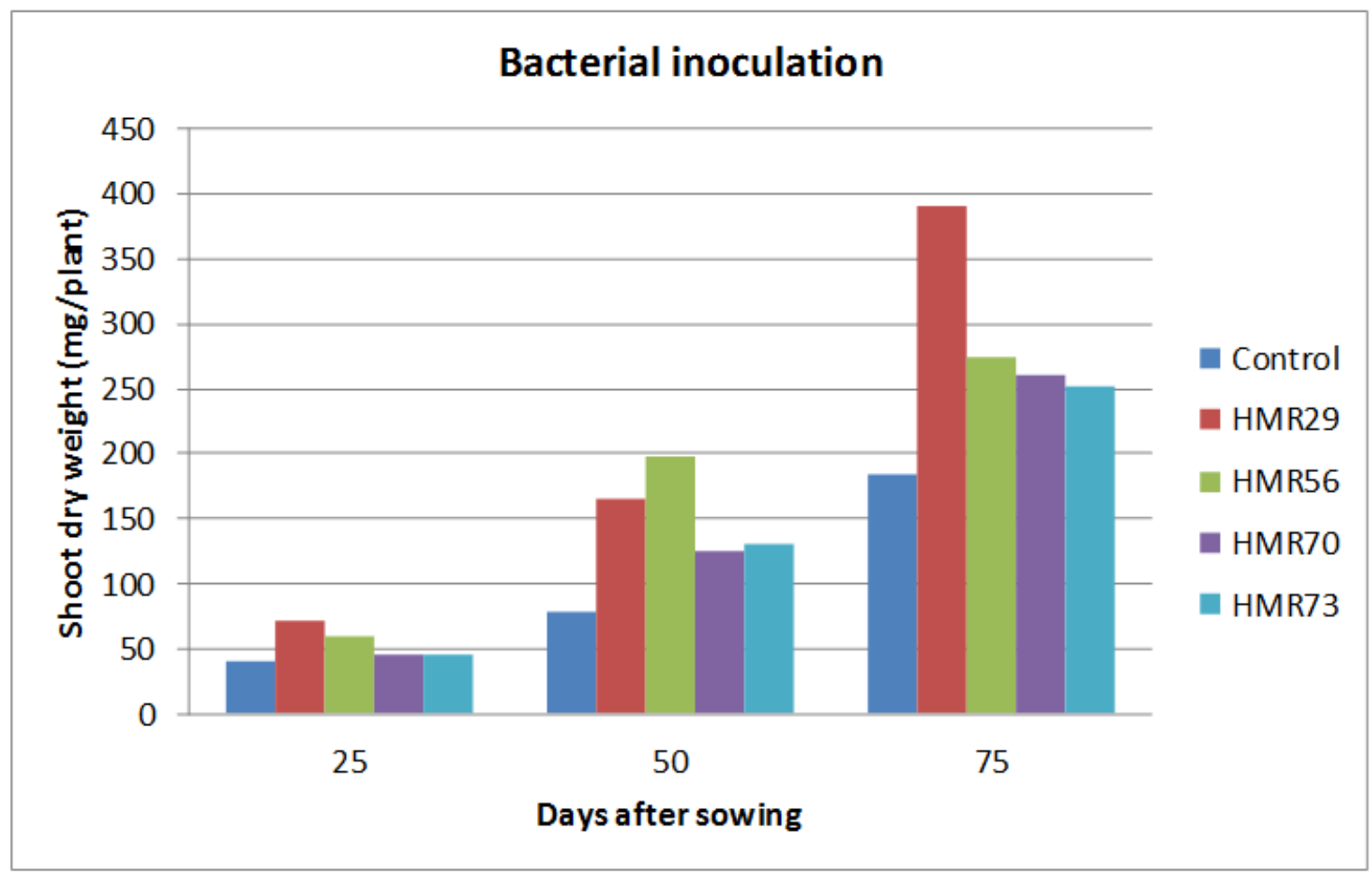


Table.1 Production of IAA and ALA by different rhizobacterial isolates

\begin{tabular}{|l|l|l|l|l|l|}
\hline $\begin{array}{l}\text { Rhizobacterial } \\
\text { isolates }\end{array}$ & $\begin{array}{l}\text { IAA } \\
(\boldsymbol{\mu g} / \mathrm{ml})\end{array}$ & $\begin{array}{l}\text { ALA } \\
(\boldsymbol{\mu g} / \mathbf{m l})\end{array}$ & $\begin{array}{l}\text { Rhizobacterial } \\
\text { isolates }\end{array}$ & $\begin{array}{l}\text { IAA } \\
(\boldsymbol{\mu g} / \mathbf{m l})\end{array}$ & $\begin{array}{l}\text { ALA } \\
(\boldsymbol{\mu g} / \mathbf{m l})\end{array}$ \\
\hline HMM26 & 1.08 & 10.70 & HMR55 & 1.80 & 10.12 \\
\hline HMM47 & 1.47 & 12.37 & HMR56 & 0.33 & 11.58 \\
\hline HMM49 & 1.65 & 14.45 & HMR57 & 0 & 19.95 \\
\hline HMM51 & 1.11 & 6.45 & HMR59 & 1.02 & 12.03 \\
\hline HMM86 & 1.14 & 13.95 & HMR65 & 0 & 8.58 \\
\hline HMM92 & 1.59 & 11.70 & HMR69 & 0 & 10.37 \\
\hline HMM109 & 2.53 & 12.16 & HMR70 & 1.47 & 8.66 \\
\hline HMR2 & 0 & 16.45 & HMR73 & 1.02 & 10.74 \\
\hline HMR3 & 0 & 9.66 & JMM4 & 2.29 & 6.99 \\
\hline HMR10 & 0 & 11.03 & JMM16 & 2.17 & 12.87 \\
\hline HMR29 & 1.77 & 14.66 & JMM18 & 2.53 & 10.45 \\
\hline HMR32 & 0.09 & 16.33 & JMM19 & 2.02 & 10.70 \\
\hline HMR33 & 0 & 10.29 & JMM23 & 1.71 & 12.24 \\
\hline HMR39 & 0 & 17.99 & MSA4 & 1.05 & 6.99 \\
\hline HMR48 & 12.11 & 10.53 & WHA64 & 1.20 & 10.91 \\
\hline HMR52 & 10.37 & 2.68 & WHA99 & 1.17 & 11.58 \\
\hline
\end{tabular}

Table.2 Solubilization of potassium and phosphorus by different rhizobacterial isolates

\begin{tabular}{|c|c|c|c|c|c|}
\hline $\begin{array}{l}\text { Rhizobacterial } \\
\text { isolates }\end{array}$ & $\begin{array}{l}\text { Potassium } \\
\text { solubilising } \\
\text { index } \\
(\text { K-SI) }\end{array}$ & $\begin{array}{l}\text { Phosphorus } \\
\text { solubilization } \\
\text { activity }\end{array}$ & $\begin{array}{l}\text { Rhizobacterial } \\
\text { isolates }\end{array}$ & $\begin{array}{l}\text { Potassium } \\
\text { solubilising } \\
\text { index } \\
(\mathrm{K}-\mathrm{SI})^{\mathrm{a}}\end{array}$ & $\begin{array}{l}\text { Phosphorus } \\
\text { solubilization } \\
\text { activity }\end{array}$ \\
\hline CP130 & 2.55 & $-{ }^{b}$ & HMR56 & 3.50 & - \\
\hline HMM21 & 2.22 & - & HMR59 & - & $2 t^{c}$ \\
\hline HMM97 & 1.23 & - & HMR73 & 3.46 & - \\
\hline HMR3 & - & $t^{\mathrm{d}}$ & JMM19 & 1.45 & - \\
\hline HMR25 & - & $2+$ & JMM23 & 2.32 & - \\
\hline HMR29 & 3.25 & - & WHA64 & 3.15 & - \\
\hline HMR48 & - & $2+$ & WHA78 & 2.15 & - \\
\hline HMR52 & 3.03 & + & WSA53 & 2.65 & - \\
\hline HMR55 & 3.23 & - & & & \\
\hline
\end{tabular}

a) - : No phosphorus and potassium solubilization activity

b) 2+: Medium phosphorus solubilization activity

c) + : High phosphorus solubilization activity 
Table.3 Inoculation effect of rhizobacterial isolates on mustard growth at 25, 50 and 75 days after sowing

\begin{tabular}{|l|l|l|l|l|l|l|}
\hline & \multicolumn{5}{|c|}{ Treatments } & \multicolumn{2}{|c|}{\begin{tabular}{c} 
25 DAS \\
\cline { 2 - 7 }
\end{tabular}} & $\begin{array}{l}\text { SDW } \\
\text { (mg/plant) }\end{array}$ & $\begin{array}{l}\text { RDW } \\
\text { (mg/plant) }\end{array}$ & $\begin{array}{l}\text { SDW } \\
\text { (mg/plant) }\end{array}$ & $\begin{array}{l}\text { RDW } \\
\text { (mg/plant) }\end{array}$ & $\begin{array}{l}\text { SDW } \\
\text { (mg/plant) }\end{array}$ & $\begin{array}{l}\text { RDW } \\
\text { (mg/plant) }\end{array}$ \\
\hline T1: Soil & 35 & 08 & 59 & 35 & 85 & 44 \\
\hline T2: Soil + RDF & 40 & 22 & 79 & 42 & 185 & 75 \\
\hline T2 + HMR29 & 71 & 32 & 165 & 55 & 390 & 105 \\
\hline T2 + HMR56 & 59 & 24 & 198 & 65 & 275 & 65 \\
\hline T2 + HMR70 & 45 & 19 & 125 & 42 & 260 & 75 \\
\hline T2 + HMR73 & 46 & 18 & 130 & 40 & 275 & 80 \\
\hline $\begin{array}{l}\text { CD at 5\% level of } \\
\text { significance }\end{array}$ & 2.844 & 3.365 & 3.115 & 3.115 & 4.334 & 2.844 \\
\hline
\end{tabular}

The values given are average value of three plants. The values of plant dry weight are calculated as per plant basis. T1 treatment without RDF and inoculation is taken as control. \{SDW: Shoot dry weight; RDW: Root dry weight

Plant roots recruit beneficial PGPRs from a wide range of genera, including Acinetobacter, Alcaligenes, Azospirillum, Bacillus, Pseudomonas, Rhizobium, Serratia and others (Sindhu et al., 2017). These rhizobacteria are important due to their beneficial functions as producers of plant growth regulators, solubilizers of phosphorus, biofertilizers, biopesticides and elicitors of tolerance to abiotic and biotic stresses (Yang et al., 2007; Perez-Montano et al., 2014). In the present study, the efficacy of different rhizobacteria was studied for growthpromoting effects on mustard crop under pot house conditions.

Production of IAA and ALA has been considered as important attributes of PGPR strains that affect the plant growth in diverse ways. In the present studies, out of 78 bacterial isolates tested, 32 isolates were found to produce IAA ranging from 1.08 to $19.95 \mu \mathrm{g} / \mathrm{ml}$ (Table 1). Four isolates HMR2, HMR32, HMR39 and HMR57 produced $>15$ $\mu \mathrm{g} / \mathrm{ml}$ IAA. Production of phytohormones in chemically defined media has also been reported in other PGPR strains including Azotobacter chroococcum (Muller et al.,
1989), Pseudomonas putida (Taghavi et al., 2009), Bacillus polymyxa (Holl et al., 1988) and Pseudomonas sp. (Dubeikovsky et al., 1993; Malik and Sindhu, 2011).

Screening of rhizobacterial isolates for ALA production showed that nineteen rhizobacterial isolates produced $>10 \mu \mathrm{g} / \mathrm{ml}$ ALA and nine isolates produced ALA between 6.45 to $9.66 \mu \mathrm{g} / \mathrm{ml}$ ALA (Table 1). Hyun and Song (2007) also showed that Rhodopseudomonas strain BL6 produced low amount of ALA, whereas another strain KL9 produced $8.57 \mathrm{mg} / \mathrm{L}$ ALA after 48 hours of incubation. Khandelwal et al., (2018) observed that $80 \%$ of the rhizobacterial isolates produced ALA. Four rhizobacterial isolates showed root growth inhibition of Chenopodium album weed and three bacterial isolates caused shoot growth inhibition at both 5th and 10th day of seed germination. Based on beneficial attributes, three bacterial isolates WHA82, MSA39 and WHA100 were examined for their effect on growth of wheat and weed under pot house conditions. Inoculation of bacterial isolate MSA39 caused 43-53\% decrease in root dry weight (RDW) and $31-47 \%$ decrease in shoot dry weight 
(SDW) of Chenopodium album at 60 and 90 days of plant growth, whereas its inoculation showed 122-144\% increase in RDW and 205$124 \%$ increase in SDW of wheat. Inoculation with bacterial isolates WHA82 and WHA100 also decreased root and shoot dry weight of $C$. album at both the stages of observations.

In this study, screening of the rhizobacterial isolates for phosphorus solubilization showed that only five rhizobacterial isolates i.e., HMR3, HMR52, HMR59, HMR48, HMR25 showed $\mathrm{P}$ solubilization (Table 2). On the other hand, 13 isolates formed significant $\mathrm{K}$ solubilization zone on mica containing medium plates (Table 2; Fig. 1). Six rhizobacterial isolates i.e. HMR56, HMR73, HMR29, HMR52, HMR55 and WHA64 showed potassium-solubilizing index (K-SI) more than 3.0 whereas, 33 rhizobacterial isolates lacked potassium-solubilizing activity. Similar variation in $\mathrm{P}$ and $\mathrm{K}$ solubilization ability has earlier been reported. Badr et al., (2006) reported that K and $\mathrm{P}$ solubilization ranged from the 490 $\mathrm{mg} / \mathrm{L}$ to $758 \mathrm{mg} / \mathrm{L}$ at $\mathrm{pH} 6.5$ to 8.0 . Hu et al., (2006) isolated two phosphate and potassium solubilizing Bacillus sp. from the soils in the modified medium containing phosphorite and potassium minerals like kaolinite and potassium feldspar. Sugumaran and Janarthanam (2007) showed that K solubilizing activity of the five slime producing bacterial isolates varied from 1.90 $\mathrm{mg} / \mathrm{L}$ to $2.26 \mathrm{mg} / \mathrm{L}$ from acid leached soil. Parmar and Sindhu (2013) reported that out of 137 rhizobacterial strains tested, only $27.7 \%$ isolates formed large zone of $\mathrm{K}$ solubilization on mica containing medium plates and the amount of potassium released by different strains varied from 15 to $48 \mathrm{mg} / \mathrm{L}$.

Four rhizobacterial isolates i.e., HMR29, HMR56, HMR70 and HMR73 were evaluated for inoculation of mustard seeds (variety RH749) under pot house conditions. Seed bacterization with rhizobacterial isolates HMR29 and HMR56 showed 77.5 and 47.5\%, gain in shoot dry weight, respectively in comparison to uninoculated plants at 25 days of growth (Table 3). Enhanced plant growth stimulation was observed at 50 days of growth and isolates HMR29 and HMR56 caused 108.8 and $150.63 \%$ increase in shoot dry weight, respectively. At 75 days of growth, inoculation with isolates HMR29 and HMR56 showed 110.0 and $48.64 \%$ gain in shoot dry weight, respectively as compared to uninoculated control. Rhizobacterial isolate HMR29 showed significant increase in shoot dry weight at all the three stages of plant growth (Fig. 2). In earlier studies, two IAA and ALA producing strains of Rhodopseudomonas sp. KL9 and BL6 were found to cause efficient growth enhancement of tomato seedlings under axenic conditions (Koh and Song, 2007). Similarly, Application of Rhodopseudomonas sp. KL9 enhanced the growth, fruit formation, yield and the quality of fruit in tomato plants in greenhouse (Lee $e t$ al., 2007). Kang et al., (2016) reported that inoculation of mustard and Chinese cabbage seedlings with Acinetobacter calcoaceticus SE370 significantly increased the shoot and root lengths, fresh weight, and chlorophyll content. In similar studies, Rhizobium sp. isolated from different sources were found to produce the highest auxin $(0.087 \mathrm{mg} / \mathrm{l})$ and cytokinin $(0.047 \mathrm{mg} / \mathrm{ml})$ in the production medium (Mahalakshmi and Bhagawati, 2017) and were used the treatment of mustard seeds. Microbially produced auxin comparatively showed the fastest shoot development $(7.9 \mathrm{~cm}$ length) and leaf (length, $1.8 \mathrm{~cm}$ and width, 1.9 $\mathrm{cm}$ ) than cytokinin and control. Inoculation of $\mathrm{Cr}^{6+}$ resistant Pseudomonas sp. PsA4 and Bacillus sp. Ba32 promoted the growth of plants at 95.3 and $198.3 \mu \mathrm{g}$ of $\mathrm{Cr}^{6+} \mathrm{g}^{-1}$ soil and maximum growth was observed in the plants inoculated with strain PsA4 (Rajkumar et al., 2006). They showed that the strains PsA4 and $\mathrm{Ba} 32$ protected the plants against the 
inhibitory effects of chromium, probably due to the production of IAA, siderophores and solubilization of phosphate.

These studies suggested that the concentration of phytohormones IAA and ALA as well as the efficiency of phosphate and potassium solubilization may exert differential response on higher plants in relation to plant biomass and yield. Therefore, rhizobacterial isolates i.e., HMR29, HMR56 and HMR73 caused 110.0, 48.64 and $48.64 \%$ increase in shoot dry weight, respectively at 75 days of plant growth. Thus, interactions between plants and rhizobacteria usually enhance the establishment of specific beneficial rhizospheres and such associations between different crop species can also be crop or cultivar-specific (Berendsen et al., 2012; Hardoim et al., 2015). Therefore, inoculation tests under field conditions are essential for evaluating the impact of such beneficial microorganisms. The inoculation with beneficial rhizobacterial strains could be an ecofriendly and cost effective technology for improving growth of mustard.

\section{Acknowledgement}

Authors thank the Department of Microbiology, CCS Haryana Agricultural University, Hisar, India for providing necessary facilities for this work.

\section{Abbreviations}

ALA: $\delta$-aminolevulinic acid

IAA: Indole-acetic acid

PGPR: Plant growth promoting bacteria

\section{References}

Anzuay, M.S., Ciancio, M.G.R., Ludueña, L.M., Angelini, J.G., Barros, G., Pastor, N., and Taurian, T. 2017. Growth promotion of peanut (Arachis hypogaea
L.) and maize (Zea mays L.) plants by single and mixed cultures of efficient phosphate solubilizing bacteria that are tolerant to abiotic stress and pesticides. Microbiol. Res. 199:98-109. doi: https:// doi.org/10.1016/j.micres.2017.03.006.

Badr, M.A., Shafei, A.M., and SharafElDeen, S.H. 2006. The dissolution of K and P-bearing minerals by silicate dissolving bacteria and their effect on sorghum growth. Res. J. Agri. Biol. Sci. 2(1):5-11.

Basak, B.B., and Biswas, D.R. 2010. Coinoculation of potassium solubilizing and nitrogen fixing bacteria on solubilization of waste mica and their effect on growth promotion and nutrient acquisition by a forage crop. Biol. Fertil. Soils 46(6):641-648.

Bashan, Y., and Holguin, G. 1998. Proposal for the division of plant growthpromoting rhizobacteria into two classifications: biocontrol - PGPB (plant-growth-promoting bacteria) and PGPB. Soil Biol. Biochem. 30:12251228.

Berendsen, R.L., Pieterse, C.M., and Bakker, P.A. 2012. The rhizosphere microbiome and plant health. Trends Plant Sci. $17: 478-486$. doi:10.1016/j.tplants.2012.04.001.

Compant, S., Clément, C., and Sessitsch, A. 2010. Plant growth-promoting bacteria in the rhizo-and endosphere of plants: their role, colonization, mechanisms involved and prospects for utilization. Soil Biol. Biochem. 42(5):669-678.

Dubeikovsky, A.N., Mordukhova, E.A., Kochetkov, V.T., Polikarpova, F.Y., and Boronin, A.M. 1993. Growth promotion of blackcurrant softwood cuttings by recombinant strain Pseudomonas fluorescens BSP53a synthesizing an increased amount of indole-3-acetic acid. Soil Biol. Biochem. 25(9):1277-1281. 
Fankem, H., Nwaga, D., Deubel, A., Dieng, L., Merbach, W., and Etoa, F. X. 2006. Occurrence and functioning of phosphate solubilizing microorganisms from oil palm tree (Elaeis guineensis) rhizosphere in Cameroon. African J. Biotechnol. 5(24):2450-2460.

Franche, C., Lindström, K., and Elmerich, C. 2009. Nitrogen-fixing bacteria associated with leguminous and nonleguminous plants. Plant Soil 321(12):35-59.

Gordon, S.A. and Weber, R.P. 1951. Colorimetric estimation of indole acetic acid. Plant Physiol. 26(1):192.

Hardoim, P.R., van Overbeek, L.S., Berg, G., Pirttila, A.M., Compant, S., Campisano, A., Doring, M. and Sessitsch, A. 2015. The hidden world within plants: ecological and evolutionary considerations for defining functioning of microbial endophytes. Microbiol. Mol. Biol. Rev. 79:293-320.

Holl, F.B., Chanway, C.P., Turkington, R., and Radhey, R.A. 1988. Response of crested wheatgrass (Agropyron cristatum L.), perennial ryegrass (Lolium perenne) and white clover (Trifolium repens L.) to inoculation with Bacillus polymyxa. Soil Biol. Biochem. 20:19-24.

Hotta, Y., Tanaka, T., Takaoka, H., Takeuchi, Y., and Konnai, M. 1997. Promotive effects of $\delta$-aminolevulinic acid on the yield of several crops. Plant Growth Regul. 22(2):109-114.

Hu, X., Chen, J., and Guo, J. 2006. Two phosphate and potassium solubilizing bacteria isolated from Tianmu Mountain, Zhejiang, China. World J. Microbiol. Biotechnol. 22(9): 983-990.

Hyun, K.R. and Song, H.G. 2007. Effects of application of Rhodopseudomonas sp. on seed germination and growth of tomato under axenic conditions. J. Microbiol. Biotechnol. 17:1805-1810.
Kang, S.M., Radhakrishnan, R., You, Y.H., Lee, K.E., Kim, J.H., Joo, G.J., Kim, J.G., and Lee, I.J. 2016. Mustard and Chinese cabbage plant growth promotion by optimal medium cultured Acinetobacter calcoaceticus SE370. J. Pure Appl. Microbiol. 10(3):1693-1700.

Khandelwal, A., Sehrawat, A. and Sindhu, S.S., 2018. Growth suppression of Chenopodium album weed and growth promotion effect on wheat (Triticum aestivum L.) by inoculation of $\delta$ aminolevulinic acid producing rhizobacteria. Int. J. Curr. Microbiol. App. Sci. 7(2):1958-1971.

Koh, R.H., and Song, H.G. 2007. Effects of application of Rhodopseudomonas sp. on seed germination and growth of tomato under axenic conditions. J. Microbiol. Biotechnol. 17(11):18051810.

Lee, K.H., Koh, R.H., and Song, H.G. 2008. Enhancement of growth and yield of tomato by Rhodopseudomonas sp. under greenhouse conditions. J. Microbiol. 46(6): 641-646.

Liu, S., Zhang, G., Li, X., Zhang, J. 2014. Microbial production and applications of $\delta$-aminolevulinic acid. Appl. Microbiol. Biotechnol. 98:7349-7357.

Mahalakshmi, V., and Bhagawati, D. 2017. Testing the efficacy of phytohormones of microbial origin in promoting plant growth. J. Microbiol. Biotechnol. Res. 7(1):1-8. doi: http://dx.doi.org/ 10.24896/jmbr.2017711

Malik, D.K., and Sindhu, S.S. 2011. Production of indole acetic acid by Pseudomonas sp.: Effect of coinoculation with Mesorhizobium sp. Cicer on nodulation and plant growth of chickpea (Cicer arietinum). Physiol. Mol. Biol. Plants 17:25-32.

Mauzerall, D., and Granick, S. 1955. The occurrence and determination of $\delta$ aminolevulinic acid and 
porphobilinogen in urine. J. Biol. Chem. 219:435-446.

Muller, F., Deigele, C., and Ziegler, H. 1989. Hormonal interactions in the rhizosphere of maize (Zea mays L.) and their effects on plant development. Z Pfflanz Bordennk 152:247-254.

Parmar, P., and Sindhu, S.S. 2013. Potassium solubization by rhizosphere bacteria: Influence of nutritional and environmental conditions. J. Microbiol. Res. 3:25-31.

Pérez-Montaño, F., Alías-Villegas, C., Bellogín, R.A., Del Cerro, P., Espuny, M.R., Jiménez-Guerrero, I., LópezBaena, F.J., Ollero, F.J. and Cubo, T., 2014. Plant growth promotion in cereal and leguminous agricultural important plants: from microorganism capacities to crop production. Microbiol. Res. 169:325-336.

Persello-Cartieaux, F., Nussaume, L., and Robaglia, C. 2003. Tales from the underground: molecular plant rhizobacteria interactions. Plant Cell Environ. 26:189-199.

Pii, Y., Mimmo, T., Tomasi, N., Terzano, R., Cesco, S., and Crecchio, C. 2015. Microbial interactions in the rhizosphere: beneficial influences of plant growth-promoting rhizobacteria on nutrient acquisition process. Biol. Fertil. Soils 51:403-415.

Prajapati, K., and Modi, H.A. 2016. Growth promoting effect of potassium solubilizing Enterobacter hormaechei (KSB-8) on cucumber (Cucumis sativus) under hydroponic conditions. Intern. J. Adv. Res. Biol. Sci. 3:168173. doi: http://s-o-i.org/1.15/ijarbs2016-3-5-24.

Rajkumar, M., Nagendran, R., Lee, K.J., Lee, W.H., and Kim, S.Z. 2006. Influence of plant growth promoting bacteria and $\mathrm{Cr}^{6+}$ on the growth of Indian mustard. Chemosphere 62(5):741-748.
Sahu, G. K., and S. S. Sindhu. 2011. Disease Control and Plant Growth Promotion of Green Gram by Siderophore Producing Pseudomonas sp. Research J. Microbiol. 6(10); 735.

Sambrook, J., Fritsch, E.F., and Maniatis, T. Molecular cloning: A Laboratory Manual. Cold Spring Harbor, New York, 1989.

Sharma, S., Kumar, V., and Tripathi, R.B. 2011. Isolation of phosphate solubilizing microorganism (PSMs) from soil. J. Microbiol. Biotechnol. Res. 1(2):90-95.

Sindhu, S.S., Jangu, O.P., and Sivaramaiah, N. 2010. Genetic engineering of diazotrophic bacteria to improve nitrogen fixation for sustainable agriculture. In: Biotechnology: Emerging Trends, Sayyed, R.Z. and A.S. Patil, Editors. Scientific Publishers, Jodhpur, India, 2010. pp.73112.

Sindhu, S.S., Parmar, P., Phour, M. and Sehrawat, A., 2016. Potassiumsolubilizing microorganisms (KSMs) and its effect on plant growth improvement. In: Potassium solubilizing microorganisms for sustainable agriculture. Springer, New Delhi, pp. 171-185.

Sindhu, S.S., Rakshiya, Y.S., and Sahu, G. 2009. Biological control of soil borne plant pathogens with rhizosphere bacteria. Pest Technol. 3:10-21.

Sindhu, S.S., Sehrawat, A., Sharma, R., Dahiya, A. and Khandelwal, A., 2017. Belowground microbial crosstalk and rhizosphere biology. In: Plant-Microbe Interactions in Agro-Ecological. Springer, Singapore, pp. 695-752.

Sindhu, S.S., Suneja, S., and Dadarwal, K.R. 1997. Plant growth-promoting rhizobacteria and their role in improving crop productivity. In: Dadarwal KR, Editor. Biotechnological 
Approaches in Soil Microorganisms for Sustainable Crop Production, Scientific Publishers, Jodhpur, 1997. pp.149-191.

Smirnova, I.E., Sadanov, A.K., and Galimbaeva, R.S. 2016. Biological method for improving germination and productivity of melilot. Recent Trends in PGPR Res. Sust. Crop Product. 21:28-36.

Sugumaran, P., and Janarthanam, B. 2007. Solubilization of potassium containing minerals by bacteria and their effect on plant growth. World J. Agril. Sci. 3:350-355.

Taghavi, S., Garafola, C., Monchy, S., and Newman, L. 2009. Genome survey and characterization of endophytic bacteria exhibiting a beneficial effect on growth and development of poplar trees. Appl. Environl. Microbiol. 75:748-757.

Welbaum, G., Sturz, A.V., Dong, Z., Nowak, J. 2004. Fertilizing soil microorganisms to improve productivity of agroecosystems. Critical Rev. Plant Sci. 23:175-193.

Yang, S., Zhang, Q., Guo, J., Charkowski, A.O., Glick, B.R., Ibekwe, A.M., Cooksey, D.A., and Yang, C.H., 2007. Global effect of indole-3-acetic acid biosynthesis on multiple virulence factors of Erwinia chrysanthemi 3937. Appl. Environ. Microbiol. 73(4):107988.

\section{How to cite this article:}

Ruchi Sharma, Swati Sindhu and Satyavir Singh Sindhu. 2018. Bioinoculation of Mustard (Brassica juncea L.) with Beneficial Rhizobacteria: A Sustainable Alternative to Improve Crop Growth. Int.J.Curr.Microbiol.App.Sci. 7(05): 1375-1386.

doi: https://doi.org/10.20546/ijcmas.2018.705.163 